\title{
Justificatory Theories for Intellectual Property Viewed through the Constitutional Prism
}

\section{Du Bois*}

\section{P.E.R}

Pioneer in peer-reviewed, open access online law publications

Author

Mikhalien du Bois

Affiliation

University of South Africa

Email

dboism@unisa.ac.za

Date of submission

20 March 2017

Date published

16 March 2018

Editor Prof O Fuo

How to cite this article

DU BOIS M "Justificatory Theories for Intellectual Property Viewed through the Constitutional Prism" PER / PELJ 2018(21) - DOI http://dx.doi.org/10.17159/1727$3781 / 2018 / v 21$ i0a2004

\section{Copyright}

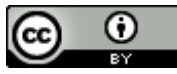

DOI

http://dx.doi.org/10.17159/17273781/2018/v21i0a2004

\begin{abstract}
In order to determine the extent to which intellectual property rights should enjoy protection under the constitutional property clause, some of the classical and newer justificatory theories for property may be employed, including the labour theory, reward theory, incentive theory, theory of natural law, spiritual theories, personality theory, economic theory, and theory of natural monopoly. These theories must be applied in line with the Constitution of the Republic of South Africa, 1996, keeping in mind that other fundamental rights must be balanced with the protection afforded to intellectual property in order to ensure its continued production. It is also important that intellectual property statutes be developed to promote a thriving intellectual commons.
\end{abstract}

\section{Keywords}

Constitutional property; intellectual property; justificatory theories; labour theory; reward theory; incentive theory; theory of natural law; excludability; spiritual theories; personality theory; economic theory; theory of natural monopoly; intellectual commons; public domain. 


\section{Introduction}

An important question that forms part of an analysis of constitutional property protection for intellectual property rights ${ }^{1}$ is whether (or rather when) protection for these interests may be justified. This necessitates an analysis and discussion of the reasons why intellectual property rights ${ }^{2}$ and unconventional intangible property interests ${ }^{3}$ should be protected. The classical property theories and some newer theories appear to justify protection of intellectual property rights, but for some of the unconventional forms of intangible property interests, other theories could be more relevant for their justification. For example, traditional knowledge protection may be better justified by theories of distributive justice.

Intellectual property rights are relations between individuals, as is the case with other property rights. However, intellectual property law pertains to rights in abstract objects. It is necessary to ask whether the legal recognition and protection of intellectual property may be explained and justified by utilising general property theories or whether a distinctive theory of intellectual property needs to be developed. ${ }^{4}$ Intellectual property should be approached in terms of property rights instead of treating it in terms of the language of privileges ${ }^{5}$ and in South African law this appears to be the case: intellectual property statutes provide property rule-type protection to intellectual creations and private law respects this position. With the increasingly important function of intellectual property ownership, the legal

Mikhalien du Bois. LLB LLD (Stellenbosch University). Associate Professor: Department of Mercantile Law, Unisa, South Africa. E-mail: dboism@unisa.ac.za. This article was presented at the Association for Law, Property, and Society's $6^{\text {th }}$ Annual Meeting in May 2015 at the University of Georgia Law School, Athens, USA. Special thanks to the late Prof AJ van der Walt for enabling my understanding of property law theories. Thank you to Prof CJ Visser for comments on this article. The Unisa School of Law Research and Innovation Fund made this visit to the University of Georgia Law School possible financially.

$1 \quad$ See Du Bois 2012 SA Merc LJ 177-193; Van der Walt and Shay 2014 PELJ 52-85.

2 These rights include but are not limited to patents, copyright, designs and trademarks. They are protected in terms of property rules under the Patents Act 57 of 1978, Copyright Act 98 of 1978, Designs Act 195 of 1993, and Trade Marks Act 194 of 1993 , respectively.

3 These interests may include commercial information, confidential information, trade secrets, digital copyright, biotechnological products, traditional knowledge, commercial property, participatory claims and non-proprietary rights.

4 Drahos Philosophy of Intellectual Property 1; Hughes 1988 Geo LJ 288: In determining whether the law of intellectual property reflects general theories of property, one should keep in mind what the theory of intellectual property should be, and determine from that what the law should be.

$5 \quad$ Drahos Philosophy of Intellectual Property 2. 
rules are becoming strained. ${ }^{6}$ The institutions of intellectual property need to be scrutinised carefully ${ }^{7}$ and particularly in South African law needs to conform to the Constitution of the Republic of South Africa, 1996 (the Constitution). However, the focus should fall on identifying which aspects of existing intellectual property law are supported (in varying degrees) by the existing theories, and which have shortcomings when viewed through the theories. ${ }^{8}$

The nonexclusive character of intellectual property objects and the restriction of the free flow of information pose challenges to the justification of intellectual property rights. ${ }^{9}$

\begin{abstract}
These objects are nonexclusive: they can be at many places at once and are not consumed by their use. The marginal cost of providing an intellectual object to an additional user is zero, and though there are communications costs, modern technologies can easily make an intellectual property object unlimitedly available at very low cost. ${ }^{10}$
\end{abstract}

The nonexclusive character of intellectual property characterises it as a physically non-excludable resource. ${ }^{11}$ It may still become legally excludable if the requirements in applicable legislation are met by the creator. Where such protection is not utilised, the intellectual creation would also become legally non-excludable with no subsequent available property protection.

Sharing intellectual property objects does not prevent or impair the personal use of their creator, but prevents the creator from exclusive financial benefit. ${ }^{12}$ The purpose of a justification of intellectual property is to explain why one person should have "the exclusive right to possess and use something which all people could possess and use concurrently". ${ }^{13}$ Exclusive use is not required for personal use in the context of intellectual property as it is with tangible property. This must be kept in mind while discussing the justifications for intellectual property. The fundamental value that society places on freedom of expression and thought must also be considered while justifying intellectual property rights, since private property improves one person's freedom to the detriment of all other persons'

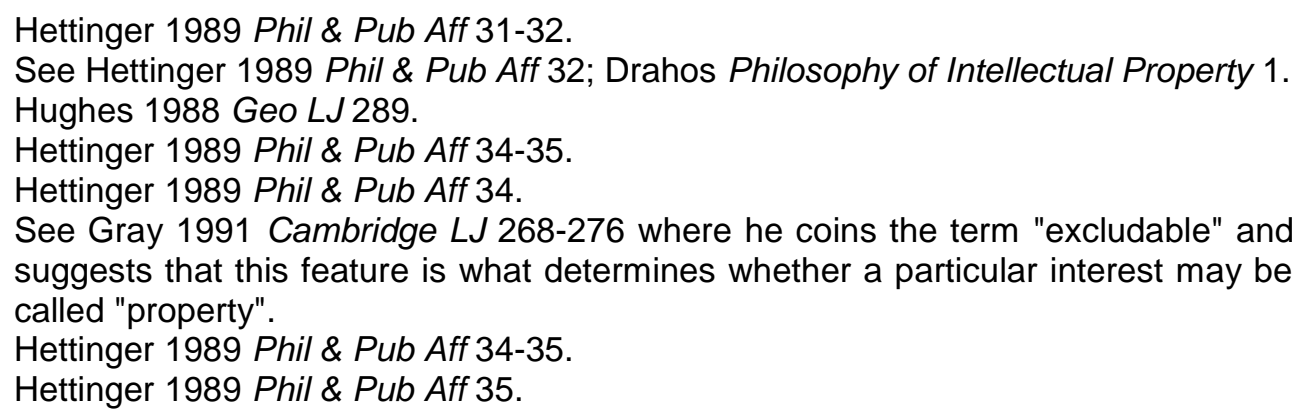


freedom. Further, restrictions on the free flow of information through the granting of intellectual property rights may impede the general advancement of new technologies and knowledge. ${ }^{14}$

At this point one must remember the difference between property protection in private law (through intellectual property statutes and the common law) and property protection in constitutional law (through the constitutional property clause), ${ }^{15}$ and also the different purposes served by private law protection and constitutional law protection. The purpose of property protection in private law is to get strong property rule-type protection for private rights against competing private parties. ${ }^{16}$ Constitutional property protection provides bill of rights-type protection for private interests against the state and competing constitutional rights of other private parties.

The South African constitutional property clause not only protects property, but provides for expropriation and deprivation by the state, although there are strict requirements that need to be met for such actions to be constitutionally justifiable. This is important where intellectual property rights conflict with other rights such as those to the public domain, human dignity, education, or freedom of expression, and they need to be weighed up during constitutional interpretation. ${ }^{17}$ This article does not present a unified constitutional property theory for intellectual property rights. However, it does highlight and explain the justificatory theories for property that may be applied to intellectual property, while taking cognisance of the limitations of the theories in view of the purpose of the Constitution, and particularly section 25 (the property clause). In line with André van der Walt's descriptive and normative thesis that the legal protection of property rights does and should play a 'modest systemic role in the law', ${ }^{18}$ intellectual property rights have taken a back-seat in constitutional jurisprudence where intellectual property rights had to be interpreted in line with non-property constitutional rights. For example, in Laugh It Off $v$ South African Breweries ${ }^{19}$ there had been a trade mark right that was clearly protectable in terms of trade mark law, but despite this, the right was trumped by the constitutional right to freedom of expression. The justificatory theories for intellectual property

Hettinger 1989 Phil \& Pub Aff 35-36; Van der Walt and Du Bois 2013 Stell LR 31-54.

Section 25 of the Constitution.

See Calabresi and Melamed 1972 Harv L Rev 1089-1128.

See Du Bois 2012 SA Merc LJ 177-193.

Van der Walt $2014 \mathrm{~J} L$ Prop \& Soc'y 26-27.

Laugh it Off Promotions CC v South African Breweries International (Finance) BV t/a

Sabmark International (Freedom of Expression Institute as Amicus Curiae) 20061

SA 144 (CC). For a discussion of the implications of this case, see Du Bois 2012 SA Merc LJ 188-191. 
protection could play a role in assessing the relative value of a particular intellectual property right as compared to the relative value of the competing non-property right, in order to find a constitutionally acceptable level of protection for each right.

South African scholarship has largely neglected the justificatory theories underpinning intellectual property law. The definitive South African intellectual property books dedicate no more than a page or two to the subject. $^{20}$ This may be attributed to the fact the neither legislation nor jurisprudence explicitly refers to the reasons why intellectual property should receive legal protection. Even the Draft Intellectual Property Policy of the Republic of South Africa (Phase 1) 2017 does not explicitly state the underpinnings of the protection of intellectual property, although commendably it does strive to "[advance] a balanced and coordinated approach to [intellectual property] that regulates [intellectual property rights] in line with the South African Constitution". It also alludes to "the proverbial bargain that the patent holder is supposed to strike with society, namely, disclosure in return for monopoly protection...". In other words it implicitly relies on the incentive theory, at least for the category of patents.

There are arguments that the fixed term of intellectual property rights (with the possible exclusion of trademark rights which are perpetual in principle) makes them fit even better under the justificatory property theories than other forms of property. ${ }^{21}$ As justificatory theories for intellectual property,

20 Pistorius "Introduction" 144-145 briefly mentions some broad justifications for copyright protection (the natural-justice, economic, cultural and social arguments) and also mentions Biotech Laboratories (Pty) Ltd v Beecham Group Plc 20023 All SA 652 (SCA) 659, a copyright case that alluded to a philosophical underpinning. Van der Merwe "Introduction" 267 mentions the quid pro quo for the granting of monopoly rights via a patent, namely full disclosure of the invention (which corresponds with the incentive theory). Ramsden Guide to Intellectual Property 1-2 mentions immaterial property rights but does not discuss any theoretical underpinnings for the protection of intellectual property law; Blignaut "Copyright" mentions the incentive theory underpinning copyright. Grant "Patents" 239 mentions the quid pro quo involved with patents. Burrell South African Patent and Design Law 1.1 dedicates a few paragraphs to explaining the quid pro quo in the context of patent law, and at 9.1 explains the quid pro quo in the context of designs. Webster and Page South African Law of Trade Marks make no mention of any justifications for protecting trade marks, and nor do any of the other South African intellectual property law books. Dean Handbook of South African Copyright Law 1.1 refers to the "own effort" requirement for copyright subsistence, which may allude to the labour theory, and at 1.2 mentions the reward and incentive theories as the underpinning for copyright protection as well as for patents and designs.

21 Hughes 1988 Geo LJ 296. On the submission of Proudhon What is Property? 11-12 that "all Property is theft" Hughes 1988 Geo LJ 289-290 suggests that this slogan is incoherent on a literal reading since "the idea of theft presupposes that someone else holds legitimate title and that all property must either be justified on labour and 
both the labour ${ }^{22}$ and personality theory have received much criticism. The personality theory as derived from the works of Kant and Hegel postulates that "an author's personality, spirit and will cannot be free unless the author owns his/her work". ${ }^{23}$ Radin's ${ }^{24}$ development of the personality theory is also important. This article discusses these theories and their criticisms, as well as other alternative and supplementary theories.

One version of the economic theory states that since intellectual property is made scarce through artificial constraints imposed by a legal framework and restricts public access to the intellectual work, a justification for intellectual property rights should be founded on the creation and protection of investor value. ${ }^{25}$ Another fairly recent theory is the theory of natural monopoly, ${ }^{26}$ which applies criticisms from natural monopoly theory to the intellectual property system. The intellectual commons is a final consideration in a discussion of the justifications for intellectual property, but it is not the focus of this article. ${ }^{27}$ The purpose of this article is to discuss each theory that may justify the legal recognition and protection of intellectual property rights as well as their criticisms. Some preliminary suggestions are also supplied as to the particular suitability of applying each theory to intellectual property rights.

/ or personality theories or would constitute theft". Ciro 2005 JILT 2 would add the economic theory to this list, but maintains that the justifications used for tangible property cannot apply to intellectual property due to their lack of scarcity (their use is non-exclusive). Mostert 1987 SALJ 480 views the labour theory as one of the most important in support of the recognition of intellectual property rights.

For example, Ciro $2005 \mathrm{JILT} 2$ argues that there is no natural right to intellectual property in the sense that John Locke argued for a labourer's natural property right to an item that is created with her labour. See also Van der Walt $2014 \mathrm{~J} L$ Prop \& Soc'y 34-35, where he highlights the relational rights theory criticism against a natural rights based justification for property that "it effectively removes contested questions about the distribution of property and of power from the realm of normative debate and political contestation".

$23 \quad$ Ciro 2005 JILT2.

24 Radin 1982 Stan L Rev 957-1015. See Van der Walt 2014 J L Prop \& Soc'y 38-39 where he notes that for the personhood theory, property only safeguards personhood regarding minimum access to property, such as access to medical care or education. Applied to intellectual property rights, this would imply that existing patent rights could be limited in the interest of medical care, or existing copyrights in the interest of education.

$25 \quad$ Ciro 2005 JILT2.

26 This theory is expounded by Ghosh $2008 \mathrm{U}$ III L Rev 1128.

27 For an introduction to the issues surrounding the intellectual commons see Van der Walt and Du Bois 2013 Stell LR 31-54. 


\section{The theory of natural law and labour theory}

\subsection{Introduction}

The theory of natural law is derived from the principle that one owns that which one creates by one's own (intellectual) effort and labour. ${ }^{28}$ At least for South African law, Roman law may be a starting point in the development of a natural-law theory for the recognition of intellectual property.

The first emergence of a natural-law justificatory theory for intellectual property may be seen in Roman jurists' treatment of specificatio, ${ }^{29}$ scriptura, pictura and occupatio. ${ }^{30}$ In these cases one owner loses ownership of a thing due to another person's "occupation" of that thing. ${ }^{31}$ Own work and value is added in such a way that the original item loses its independence and ceases to exist as a thing. ${ }^{32}$ Roman jurists acknowledged that the labour of one person could increase the value of the resultant thing to the point where the added value was higher than the original, and this entitled him to ownership of the new product. ${ }^{33}$

A first step towards recognising intellectual property on natural-law principles is evident in the rules of pictura, where the painter, and not the owner of a tablet upon which such painting was done, became the owner of the finished work. ${ }^{34}$

From the seventeenth century onwards, Roman-Dutch law authors emphasised the importance of writing and the intellectual labour spent to create the work. The natural-law principle determined ownership for specificatio, scriptura, pictura and occupatio. In conjunction with eighteenth

$28 \quad$ Mostert 1987 SALJ 480.

29 Specificatio takes place when one person's property is converted by another person who is not the owner of the original thing. See Badenhorst, Pienaar and Mostert Silberberg and Schoeman's The Law of Property 156. order to acquire ownership. This pertains to a corporeal movable or immovable thing in the sphere of private law (res in commercio) which is not owned by anyone. This has to be done with the intention of becoming owner of the thing. See Badenhorst, Pienaar and Mostert Silberberg and Schoeman's The Law of Property 137. Mostert 1987 SALJ 481-485. See Badenhorst, Pienaar and Mostert Silberberg and Schoeman's The Law of Property 141-156. Schoeman's The Law of Property 156-159 and sources cited there. Mostert 1987 SALJ 484-485. 
century philosophical influences, this express recognition of the natural-law principle founded modern recognition of intellectual property. ${ }^{35}$

\section{$2.2 \quad$ Locke's labour theory}

Seventeenth century and later legal scholars accorded the natural-law principles a larger role in recognising intellectual property. John Locke ${ }^{36}$ justified property on the basis that every person has a property in his own person, own labour, and works created through own labour. By "mixing" one's labour with land or other tangible property, a "natural right" to the property is acquired. ${ }^{37}$ This principle of acquiring property over one's own intellectual creations played an important role in the recognition of intellectual property rights, especially patents and copyright. ${ }^{38}$ However, whether the labour theory can be successfully applied to intellectual property is an open question.

According to Hettinger 39 "[p]erhaps the most powerful institution supporting property rights is that people are entitled to the fruits of their labor". The labour theory postulates that the products of a person's own intelligence, effort and perseverance should belong to that person and to no one else. The object would not exist but for that person creating it. ${ }^{40}$

\subsection{The revised labour theory}

According to Munzer, ${ }^{41}$ desert based on labour should not be the only justification for private property rights, even though it is important. An initial and revised theory based on labour and desert may be identified. In this context, labour means "the exertion of effort in order to make or physically appropriate something" and desert "worthiness of some recompense

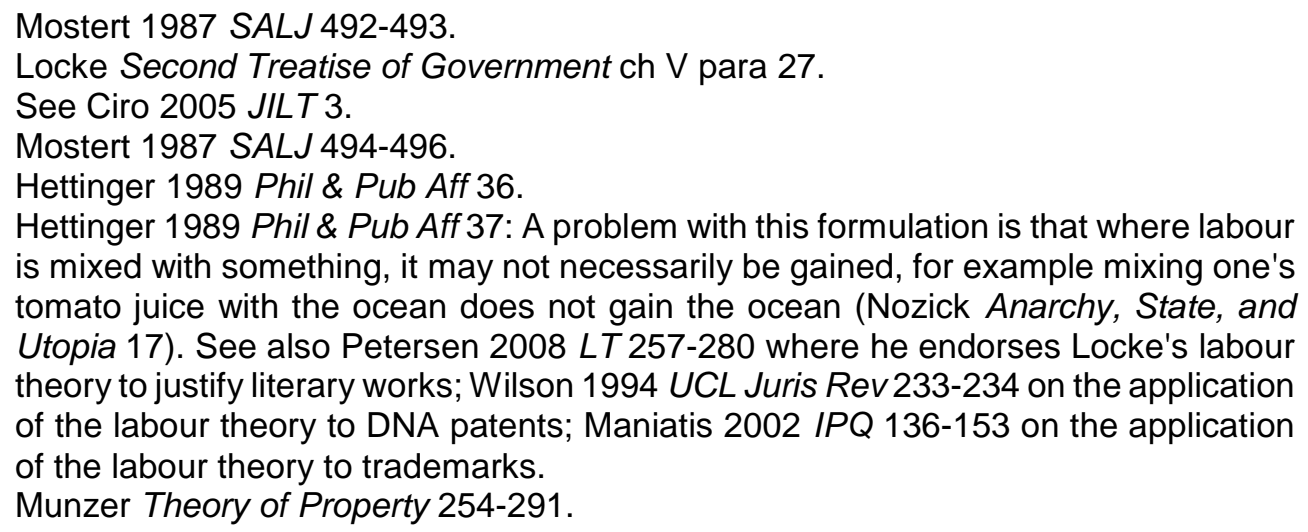
is mixed with something, it may not necessarily be gained, for example mixing one's tomato juice with the ocean does not gain the ocean (Nozick Anarchy, State, and Utopia 17). See also Petersen 2008 LT 257-280 where he endorses Locke's labour theory to justify literary works; Wilson 1994 UCL Juris Rev 233-234 on the application of the labour theory to DNA patents; Maniatis 2002 IPQ 136-153 on the application of the labour theory to trademarks. Munzer Theory of Property 254-291. 
because of some personal feature or action". ${ }^{42}$ Munzer ${ }^{43}$ outlines the labourdesert theory:

If the background conditions ${ }^{44}$ exist, then the laborer may use his body to gain control over something. If, further, there exist the features of the laboring situation ${ }^{45}$ and the physical and psychological effects described, ${ }^{46}$ then the laborer is responsible for a product that he does not misuse and over which his enduring control has no adverse impact on others. If, finally, the evaluative and normative features are as specified, ${ }^{47}$ then recognizing his enduring control is the most fitting benefit for his labor and does not infringe the rights of others. Such recognition is the acknowledgement of property rights.

The initial labour theory claims that the labourer would deserve "moral property rights in the product in virtue of his labor". 48

Munzer ${ }^{49}$ suggests the revised labour theory to make the assumptions of the initial labour theory more realistic. First, the labourer's property rights need to be qualified by broader duties arising from the rights of nonlabourers (for example the right to the necessities of life). The assumption of no waste is also unrealistic and necessitates a power of transfer. ${ }^{50}$ Examples of such rights of non-labourers are the right to freedom of speech, education or other political and socio-economic rights.

The assumption that property is justified when there are similar things in sufficient quantity and quality left for other people and that they lose nothing by the labourer's acquisition (the enough and as good as left presupposition) could be made more realistic by relying on the principles of utility and

$42 \quad$ Munzer Theory of Property 256-257.

$43 \quad$ Munzer Theory of Property 259.

$44 \quad$ Munzer Theory of Property 258: The background conditions assume that there is no society or government, the thing that the labourer hopes to acquire is not owned, there is a sufficient amount of these things with sufficient quality, and the labourer has the liberty to use his body for the work required.

$45 \quad$ Munzer Theory of Property 258: These features are that the labourer has no moral duty to work, the purpose of working is to acquire enduring control over a thing, the labourer works alone and not for someone, the work done involves physical contact with the thing, the work does not reflect how the labourer sees himself in relation to others, and all workers work equally intense and effective. Munzer Theory of Property 258: The physical and psychological effects refer to the fact that the labourer produces a product and not a service, the product is not wasted, and others are not adversely affected by the creation or gathering of the product. Munzer Theory of Property 258: These features are that the product is good in a general sense, that no one besides the labourer benefits from the product, property rights would not be transferable and would be exclusive, the rights would last indefinitely, the rights would be the most appropriate benefit for the labourer's work, and they would not infringe any other persons' rights. Munzer Theory of Property 259.

49 Munzer Theory of Property 266-291. Munzer Theory of Property 267-269. 
efficiency; and justice and equality to constrain the acquisition process. So outside limits on acquisition through an understanding of social complexities are also necessary. ${ }^{51}$ The scarcity problem makes it impossible for acquisition not to change the position of other persons, so exclusive rights with no expiry date are not supported by the revised labour theory, but rather restricted property rights. ${ }^{52}$ Most intellectual property rights are exclusive (bar the few exceptions provided for in applicable legislation), but for a limited duration. Although trademark rights are perpetual in principle (they may be renewed subject to continued use), they very distinctly subscribe to the use-it-or-lose-it principle. Like other property rights, intellectual property rights are not absolute and may be limited by socio-economic rights and other fundamental rights where such rights are more pressing in a given situation. Intellectual products are not scarce like land, in the sense that more can be created.

Intellectual property is about creation and does not "use up" resources in the way that the creation of physical property does. However, information resources are taken from the intellectual commons in order to create intellectual products. Once taken from the intellectual commons and propertised, these resources are no longer available for other persons to use in future intellectual creations. The revised labour-desert theory holds that labour may still serve as a prima facie justification for property rights, but embodied as rights qualified by external restrictions. In terms of South African law, some of these external restrictions would entail expropriation and deprivation of property rights based on the need to promote other human rights.

\subsection{Possible application of the labour theory to intellectual property}

There are many interpretations of Locke's philosophies about property, but labour has a relatively small role in the so-called "labour theories of property". Drahos ${ }^{53}$ views Locke's writings on property as valuable for justifying intellectual property rights because it shows that such a naturalrights justification relies heavily on a concept of community and its metaphysical scheme.

Locke's philosophy attempts to address the issue that the earth belonged to "Mankind in common", with individual property posing a problem. Natural law proclaimed the existence of a commons, but also had to explain private

\footnotetext{
$51 \quad$ Munzer Theory of Property 269-274.

52 Munzer Theory of Property 274-276.

53 Drahos Philosophy of Intellectual Property 41.
} 
ownership. ${ }^{54}$ Locke's solution ${ }^{55}$ was that "every Man has a 'Property' in his own 'Person'. Where a person mixes his own labour with something which had previously been in the commons, the thing becomes his property".

Locke ${ }^{56}$ placed two provisos on this justification: that "enough and as good [must be] left in the commons for others" and preventing spoilage. The first proviso means that as long as another's position is not worsened by one's appropriation of a resource, ownership based on labour is permitted. ${ }^{57}$ Some argue that patent law does not pass muster under this proviso since inventors who independently invent an already patented creation are not even allowed to use their own inventions. ${ }^{58}$ The "enough and as good" proviso describes the commons but also references the natural ceiling on how much each person can appropriate through labour owing to the limited capacities of humans. ${ }^{59}$

The second proviso mandates preventing spoilage: one must not take more than one is able to use. It may be argued that intellectual property will never be able to meet this proviso entirely due to the nonexclusive nature of intellectual property. The relative benefit of products would determine how wasteful prohibition of its use by third parties would be. ${ }^{60}$

However, the intellectual property rights granted by statutes do not have the purpose of granting exclusive use rights, but rather the right to prohibit third persons from doing certain exclusive acts with the work. An example may be the copyright in a book which does not grant the exclusive right to read the book. Anyone who is willing to pay a fee to read a legal copy is allowed to read it. Only when third persons wish to copy and distribute the book (in other words to do one or more of the acts that fall within the copyright owner's sphere of exclusivity), the rights granted by copyright become relevant. Copyright grants the holder the mainly negative right of preventing third persons from taking away the remuneration to which the copyright holder is entitled. In other words, it is not exclusive personal use and

$54 \quad$ Drahos Philosophy of Intellectual Property 42.

55 Locke Second Treatise of Government ch V para 27; Drahos Philosophy of Intellectual Property 43; Hughes 1988 Geo LJ 297. Locke's discussion begins with the description of "a state of nature in which goods are held in common through a grant from God ... The individual must convert these goods into private property by exerting labor upon them. This labor adds value to the goods, if in no other way than by allowing them to be enjoyed by a human being". Locke Second Treatise of Government ch V para 27.

Hettinger 1989 Phil \& Pub Aff 44; Drahos Philosophy of Intellectual Property 42-43. Hettinger 1989 Phil \& Pub Aff 44.

Hughes 1988 Geo LJ 297-298.

Hettinger 1989 Phil \& Pub Aff 44-45. 
enjoyment of the product that is protected by intellectual property rights, but rather the rights to exploit the product that are reserved for exclusive use by the intellectual property owner.

These property rights (or at the very least, the statutes provide property ruletype remedies and private law honours this position) may be justified by the labour theory without contravening the two provisos. This analysis is applicable to copyright, patents, designs and trademarks. Since the relative benefit for third parties from use of trade-mark rights may be viewed as very low (it is a purely commercial right - and has no benefit such as educational in the case of copyright or medicinal as in the case with some patents) this may account for the relatively high excludability of trade-mark rights.

The question of why labour should serve as the justification for ownership and not, for instance, intention or possession ${ }^{61}$ takes on a utilitarian form in Locke's answer: ${ }^{62}$ just reward for labour is appropriate because it has social benefits. Locke 63 implies that the common stock of mankind is increased by granting property to people who create things through own labour. "Locke's overall scheme for property can be viewed as an alloy of the labor and tacit consent theories". ${ }^{4}$ However, as long as the new wealth remains the labourer's property, this does not increase the common stock. This must be balanced with the risk that free appropriation would discourage the creation of new wealth. 65

One solution to this dilemma would rely on donations from the labourer to the commons, ${ }^{66}$ but this would render a well-stocked intellectual commons a privilege instead of a right. Locke's solution ${ }^{67}$ is the introduction of the money economy which makes wealth potentially part of the commons. Locke assumes three things here: that the individual is able to appropriate more than what can be used, that the individual will have the motivation to do so, and that (excepting waste) this is not problematic. Locke also employs tacit consent to justify his money economy. ${ }^{68}$ Locke's general

61 Drahos Philosophy of Intellectual Property 43-44; Hughes 1988 Geo LJ 298 disagrees (on the basis that Locke never refers to possession of one's body as the basis for property in one's body) with the argument of Epstein $1979 \mathrm{Ga} L J 1227$ that if possession is good enough to establish ownership in one's self, it should also be good enough to possess external things.

$62 \quad$ Locke Second Treatise of Government ch V para 27.

63 Locke Second Treatise of Government ch V para 27.

64 Hughes 1988 Geo LJ 298.

65 Hughes 1988 Geo LJ 299.

66 Hughes 1988 Geo LJ 299.

$67 \quad$ Locke Second Treatise of Government ch V para 27.

68

See Hughes 1988 Geo LJ 299. 
system for property may be viewed as a combination of labour and tacit consent theories, although the labour theory particularly is considered unique to Locke.

In his justification of intellectual property rights under Locke's labour theory, Hughes $^{69}$ uses three propositions: "first, that the production of ideas requires a person's labor; second, that these ideas are appropriated from a 'common' which is not significantly devalued by the idea's removal; and third, that ideas can be propertised without breaching the non-waste condition".

On the statement that idea production requires labour, the "avoidance" view of labour, the "value-added" labour theory, and the interaction between labour and the idea / expression dichotomy ${ }^{70}$ are relevant in testing the proposition's validity.

The "avoidance" view advocates rewarding labour with property due to its unpleasantness: property should be given to motivate people to perform labour. The creation of ideas is not so pleasant an activity that people would necessarily choose it above recreation, so this motivation provided by property rights is also relevant to intellectual products. ${ }^{71}$

The "value-added" labour theory corresponds with the "just desert" justification of property: it holds that a labourer deserves a reward for producing something holding value to others. The creation of social value deserves reward, not the labour in itself. The idea / expression dichotomy demonstrates the balancing of the need to reward creators, and free access to ideas. ${ }^{72}$ For example, the Copyright Act 98 of 1978 provides that copyright does not subsist in thoughts, ideas or facts. ${ }^{73}$

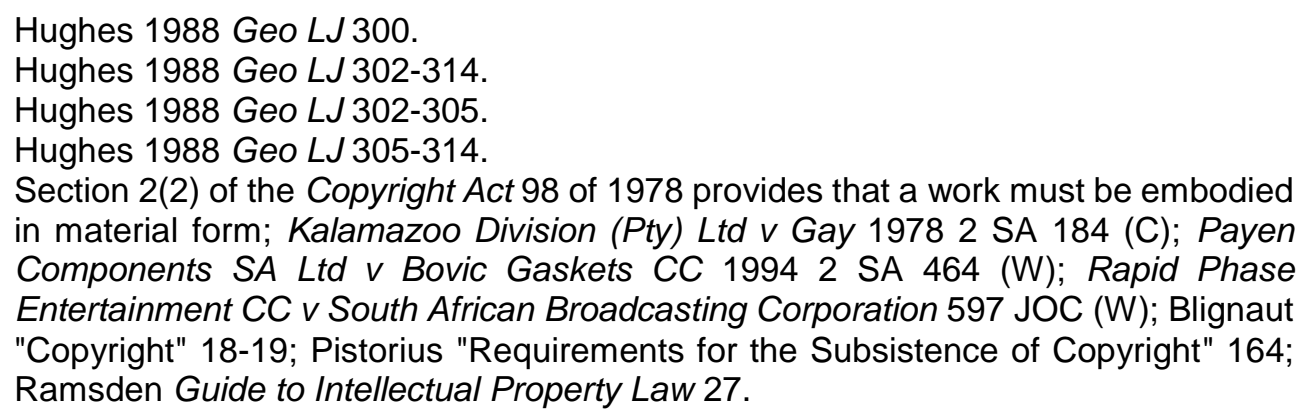
in material form; Kalamazoo Division (Pty) Ltd v Gay 19782 SA 184 (C); Payen Components SA Ltd v Bovic Gaskets CC 19942 SA 464 (W); Rapid Phase Entertainment CC v South African Broadcasting Corporation 597 JOC (W); Blignaut "Copyright" 18-19; Pistorius "Requirements for the Subsistence of Copyright" 164; Ramsden Guide to Intellectual Property Law 27. 
Tully ${ }^{74}$ and Macpherson ${ }^{75}$ provide two well-known interpretations of Locke's work on property. ${ }^{76}$ Tully's interpretation views Locke's ${ }^{77}$ philosophy as a justification of the commons and not the right to private property, while on Macpherson's interpretation, Locke provides the foundation for the justification of private property.

Drahos $^{78}$ identifies two factors that may determine how much weight could be attributed to labour as a justificatory theory for intellectual property: "a conception of community; and the relation of that community to the intellectual commons".

The interpretations of Locke's theory on property may be separated into an instrumental and a normative interpretation. An instrumental interpretation postulates that society must reward labour with property in order to get labour, while a normative interpretation suggests that a reward should be provided for labour. Either of these interpretations may be used to justify intellectual property, and such application would be free from a number of problems that affect tangible property. ${ }^{79}$ Caution must be taken to place no undue emphasis on the labour and mixing metaphor in the context of intellectual property, since the mixing of labour allows persons to appropriate part of the commons for own use in the context of physical property, but where intellectual property is concerned, this very act of labour may prevent the emergence of an intellectual commons.

An example of the influence of natural-law justification for intellectual property is visible in the 1769 English case of Millar v Taylor, ${ }^{80}$ where the court decided that literary property in a published work was recognised by common law. The recognition and protection of literary property was

\footnotetext{
$74 \quad$ Tully Discourse on Property 174-176.

75 Macpherson Political Theory of Possessive Individualism 221.

76 Drahos Philosophy of Intellectual Property 44. Locke's text encourages interpretations that are in conflict.

$77 \quad$ Locke Second Treatise of Government ch V para 27.

78 Drahos Philosophy of Intellectual Property 44. See Van der Walt and Du Bois 2013 Stell LR 31-54.

79 Hughes 1988 Geo LJ 296-297; Drahos Philosophy of Intellectual Property 47-48 agrees that Locke's theories are widely relied on for the justification of intellectual property, but cautions that Locke did have tangible property in mind at the time of writing the treatises and too much emphasis is placed on the labour and mixing metaphor. Millar v Taylor (1976) 4 Burr 2303, 98 ER 201.
} 
founded on the natural-law principle that a person should reap the rewards of his own ingenuity and labour. ${ }^{81}$

[Th]e natural law theory, which is justified on the interest of the individual to enjoy the fruits of his own labour, is still of particular prominence in the protection of modern-day intellectual property and especially new forms of intellectual property. ${ }^{82}$

A more pressing problem with the labour theory as justification for property is that it does not indicate whether a labourer would be entitled to the total value of the resulting product or only to the value that his labour has added to the resulting product. ${ }^{83}$ While Locke ${ }^{84}$ would attribute 99 percent of an object's value to human labour, Hettinger ${ }^{85}$ questions this division. This question is also relevant to intellectual property: what part of the value of inventions, writings and business information may be attributed to the intellectual labourer? While such products would not exist without the labour, it does not necessarily follow that the whole value of the creation may be attributed to the labourer.

Intellectual products are "fundamentally social products" 86 since creators use existing information to create new products. If labour equals naturalright entitlement to the market value of an intellectual creation, all the contributors should share this value. Labour does not entitle the last contributor to the full value, so market value provides limited assistance in determining the value of a creator's contribution. Market value also depends on social factors. ${ }^{87}$ While a natural right may entitle one to personal use and possession of one's creation, it does not justify entitlement to full market value. The natural right of a creator to utilise an own creation is distinct from the exclusive rights (protected by intellectual property) to make and sell copies of the work. "The 'right' to receive what the market will bear is a socially created privilege, and not a natural right at all". ${ }^{88}$

81 Mostert 1987 SALJ 496-497. This would mean that an author's right is not artificially granted by way of legislation - the legislation is merely supplementary to the natural law right of the author. Natural-law theory is not the only theory used in South African modern-day law to justify intellectual property, the reward and incentive theories also had an influence. See also Rose Authors and Owners in general on the history of copyright in the England, which is also applicable to South African copyright law, since South African statutes are based on English statutes.

82 Mostert 1987 SALJ 500.

$83 \quad$ Hettinger 1989 Phil \& Pub Aff 37.

$84 \quad$ Locke Second Treatise of Government ch V para 40.

85 Hettinger 1989 Phil \& Pub Aff 37.

$86 \quad$ Hettinger 1989 Phil \& Pub Aff 38.

87 Hettinger 1989 Phil \& Pub Aff 36-37.

88 Hettinger 1989 Phil \& Pub Aff 39-40. 
A theoretical approach viewing the state as an invention, but not individual rights - mandating the state to protect but not interfere ${ }^{89}$ - could lead to the undesirable argument that intellectual property rights should be held in perpetuity. ${ }^{90}$ Any statutory introductions such as a fixed term for intellectual property rights or compulsory licenses would be viewed as "theft". Such statutes are allowed in South African law as long as the state complies with the provisions for deprivation and expropriation as set out in the property clause. Even on this radical view, one would have to keep in mind that the state also has obligations to protect other individual rights (for example life, health, and education) and that the protection of the different rights must be balanced. The historical tradition of natural property rights does not establish the sanctity of property rights; they remain subject to regulation (in line with the purposes of natural law). ${ }^{91}$ Locke's writings cannot serve as a basis for justifying unregulatable intellectual property rights, since the labour mixing metaphor generates too many uncertainties and problems once it is stripped of its metaphysical context. ${ }^{92}$ It may serve to justify intellectual property rights that still require to be balanced with public interest in the intellectual commons and other fundamental rights.

\subsection{The intersection between excludability and the labour theory}

Excludability is a notion developed by Gray $^{93}$ to explain when a particular interest may be described as property. The question whether a particular interests may be termed property hinges on whether the interest may be deemed "excludable". "The notion of excludability ... imports a hidden structure of rules which critically define the legal phenomenon of private property." ${ }^{44}$ A resource may be deemed non-excludable based on physical, legal and moral considerations. A non-excludable resource lies forever outside the field of private property, remaining in the commons.

Physical non-excludability refers to a situation where it is impossible or impractical to prevent strangers from accessing the benefits of a resource as is. ${ }^{95}$ Victoria Park Racing $v$ Taylor ${ }^{96}$ provides such an example where purely physical reasons prevented exclusion.

Nozick Anarchy, State, and Utopia 174-178.

Drahos Philosophy of Intellectual Property 53.

Drahos Philosophy of Intellectual Property 53 - support found in Locke Second Treatise of Government ch VIII para 120.

Drahos Philosophy of Intellectual Property 54.

Gray 1991 Cambridge LJ 268-276.

Gray 1991 Cambridge LJ 269.

Gray 1991 Cambridge LJ 269.

Victoria Park Racing v Taylor (1937) 58 CLR 479.
} 


\begin{abstract}
Ultimately the risk of non-excludable benefit must rest with the plaintiff, and if the plaintiff fails, by such physical means as are at his disposal, to prevent unconsented visual intrusion into his land, the particular resource at stake the 'spectacle' - must be deemed non-excludable. No one can claim 'property' in a resource in relation to which it is physically unrealistic to control, consistently over prolonged periods, the access of strangers. ${ }^{97}$
\end{abstract}

Legal non-excludability refers to situations where the owner of a resource fails to use the available legal protection for such resource. Gray explicitly mentions the adoption of a particular regime of intellectual property as an example. ${ }^{98}$ Such example in South African law would be the amendment of intellectual property statutes ${ }^{99}$ to include the protection of traditional knowledge resources. If the holders of traditional knowledge then make no effort to utilise the available legislation, a particular product of traditional knowledge would be deemed legally non-excludable.

Morally non-excludable resources are

... simply perceived to be so central or intrinsic to constructive human coexistence that it would be severely anti-social that these resources should be removed from the commons. To propertise resources of such social vitality is contra bonos mores: the resources in question are non-excludable because it is widely recognised that undesirable or intolerable consequences would flow from allowing any one person or group of persons to control access to the benefits which they confer. Following such an appropriation, there would not, in Locke's well known phrase, be 'enough and as good left in the common for others' ... It is in the definition of moral non-excludables that the law of property most closely approaches the law of human rights. ${ }^{100}$

Certain freedoms of speech, belief, association, assembly and movement are frequently viewed as values higher than the property concept, and moral exclusion recognises the superiority of such claims above "property" claims: "Here emerges again the important point that property rights are merely prima facie rights which may be abridged or overridden by other moral concerns". ${ }^{101}$

\title{
2.6 Conclusions on the labour theory and intellectual property rights
}

In determining the extent to which a natural rights or labour theory of property may be relied on to justify intellectual property rights, the interpretation used is extremely important. The protection of intellectual

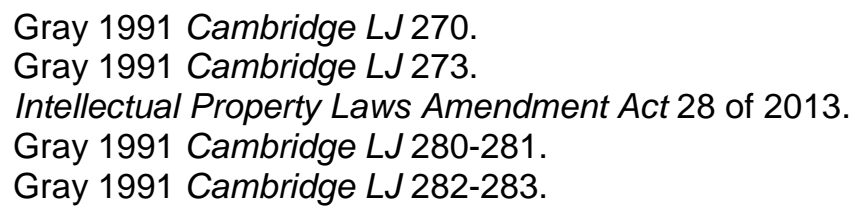


property rights (patents, works of copyright, registered designs and trademarks) may be justified by the labour theory. Every category of intellectual creation comes into existence through labour, therefore the labour theory remains one of the important justifications for intellectual property. The labour theory may have to be interpreted in such a way as to incorporate the personality theories. The labour theory does not justify unlimited, unregulatable property rights, since the labour theory never intended to justify unlimited or unfettered rights.

Gray's ${ }^{102}$ analysis of excludability as an indicator of when a particular resource receives property protection is important to intellectual property (patents, works of copyright, registered designs, trademarks and rights protected in terms of unlawful competition) since each category is created by legislation or protected in terms of common law. Provided the creator of an intellectual work utilises the legal protection, the work will be legally excludable and as such enjoy property protection (subject to limitations). Some intellectual resources will not be protected as property, but remain in the intellectual commons since they are deemed morally non-excludable, for example materials that are excluded from patentability. ${ }^{103}$

Where a particular resource enjoys no legal protection yet and it may be determined that there is no ground for moral non-excludability, an argument may still be made for such a resource to receive property protection (via a legislative amendment) based on the labour theory.

Biotechnological products may be justified by the labour theory. Although some biotechnological products are legally excludable since they are protected under patent law, some forms of biotechnological products are not patentable; which may be because they are morally non-excludable since the particular information must remain in the commons based on fundamental rights such as privacy and bodily integrity. ${ }^{104}$

102 Gray 1991 Cambridge LJ 268-276.

103 Section 25(1)(a)-(g) of the Patents Act 57 of 1978 excludes the following from patentability: discoveries; scientific theories; mathematical methods; literary, dramatic and/or artistic works; schemes, rules, methods of performing mental acts, playing games or doing business; computer programs; and presentation of information. S 25(4)(a) prevents the patenting of inventions that would encourage offensive or immoral behaviour. S 25(4)(b) prevents the patenting of varieties of plants, animals, or biological methods for their production. Medical methods of treatment (s 25(11)); inventions contrary to natural laws (s 36(1)(a)); and nuclear energy and material, and inventions contrary to law (s 36(2)) are also largely prevented.

104 For example s 25(4)(b) of the Patents Act 57 of 1978 prevents the patenting of varieties of plants, animals, or biological methods for their production. 
As evidenced by the South African process to include traditional knowledge as a form of intellectual property, ${ }^{105}$ traditional knowledge is a particularly troublesome resource. Without specific legislation protecting traditional knowledge as the property of the traditional holders, only the last person who contributes to an intellectual creation based on traditional knowledge is rewarded. When a pharmaceutical company invents a medicine based on traditional knowledge of a plant with medicinal properties, only the company is awarded a patent. The traditional community holding the knowledge is not rewarded. The labour theory, as with most of the general property theories, provides inadequate justification for the protection of traditional knowledge. Stronger justification could be found in theories of distributive justice or human rights.

\section{The reward theory}

\subsection{Introduction}

The reward theory advocates rewarding individuals not only for their own labour, but for the societal benefit of their effort (creative effort - in the context of intellectual property). ${ }^{106}$ The creator receives an exclusive intellectual property right as reward for the creative endeavours. The resource is legally excludable because legislation creates the possibility for the creators of intellectual products to invoke legal protection for these products, provided that the requirements are met as stipulated for each category. Legislation mostly provides explicitly for morally non-excludable resources. For example, the principle of "no copyright in ideas" is based on the concept that the resource must stay in the intellectual commons for utilisation by future creators.

\subsection{Possible application of the reward theory to intellectual property}

Society rewards inventors and writers in the form of a legal right to exclude other persons from certain forms of use of the work for making the works publicly available. Where intellectual property encourages disclosure of works that would otherwise remain secret, intellectual property rights (particularly patents, works of copyright and registered designs) enhance free flow of information. By contrast, trade secret requirements promote secrecy and restrict information dissemination. An important requirement is

\footnotetext{
105 Intellectual Property Laws Amendment Act 28 of 2013; Harms 2009 THRHR 175191 explains some of the difficulties experienced with the process and the amendments. 
that the information must not be widely known. ${ }^{107}$ On this interpretation, the reward theory justifies patents, copyright works and designs, but not trade secrets.

The desert theory is another variation on the reward theory: a labourer deserves to benefit from his labour. This theory does not indicate what the labourer would be entitled to, and a property right is not the only possible reward - it could also take the form of "fees, awards, acknowledgement, gratitude, praise, security, power, status and publicly financed support". ${ }^{108}$

Where a right's value is not proportionate to the effort and labour spent, the most fitting reward may not necessarily be a property right. One may not necessarily be entitled to the full value produced by the labour, since outside factors such as luck may inflate the value. ${ }^{109}$ According to Rawls, ${ }^{110}$ even one's capability to expend effort is such an outside factor, which makes value a morally impermissible criterion in determining distribution. Proportionality is an important consideration in determining the appropriate reward, since intellectual property rights may earn the owner much more value or benefits than the initial expenditure of the intellectual product's creation. ${ }^{111}$

Munzer's version of the "labour-desert" theory combines the labour and desert theories. ${ }^{112}$ The initial theory underwrites "a prima facie justification ... for a set of private-property rights in a version of the state of nature" while the revised theory supports such justification "for a somewhat different set of private-property rights in a modern society". ${ }^{113}$ While desert still plays a role in the revised labour-desert theory, it may be supplemented and even trumped by utility and efficiency, and justice and equality, respectively. ${ }^{114}$

It is possible to do comparative assessments of desert claims based on labour if the relevant features for a worker's performance assessment may be identified in order to determine a suitable compensation. Some of these features may include "effort, ability, persistence, industriousness, luck, time spent, achievement, the difficulty, unpleasantness, or danger of the work, and the working conditions" as well as "the responsibility, leadership, or

\footnotetext{
107 Hettinger 1989 Phil \& Pub Aff 36.

108 Hettinger 1989 Phil \& Pub Aff 41.

109 Hettinger 1989 Phil \& Pub Aff 42.

110 Rawls Theory of Justice 104.

111 Hettinger 1989 Phil \& Pub Aff 43.

112 Munzer Theory of Property 254-291.

113 Munzer Theory of Property 255.

114 Munzer Theory of Property 289-291.
} 
motivating capacity displayed by one worker in relation to others". Although this approach guides in generating relative values for specific kinds of labour, it discloses no absolute values, "inherent worth" of labour, or a "just price" for labour. 115

\subsection{Conclusions on the reward theory and intellectual property rights}

Where the dissemination of information is promoted by the grant of intellectual property rights, the reward theory seems appropriate. Patent rights, copyright and registered design rights seem to meet this requirement. Trade-mark rights seem to create no benefit for society except perhaps the relatively minor benefit of preventing confusion between the product or service covered by a trade mark and other (possibly inferior) products. Similar to the labour theory's shortcomings, this theory also gives no indication what form the reward should take or even whether it needs be property right-based.

For trade secrets and confidential information, the requirement is that the information not be made known - accordingly the reward theory does not apply. Digital copyright may also be justified by the reward theory even though it is protected by contract in addition to the copyright protection afforded. Biotechnological products that are not liable to remain in the public domain on conceptual grounds may be protected under patent law and as such these rights may be justified by the reward theory.

Historically, traditional communities received no reward for making their traditional knowledge known. A person who registered a patent based on traditional knowledge would receive the full reward, not the original holders of the knowledge. The application of the reward theory is distinctly limited for traditional knowledge rights claimed by indigenous groups. The original creators of the knowledge might deserve a reward, but they are no longer alive and their remote descendants would not necessarily deserve the same reward. ${ }^{116}$ Accordingly, the reward theory plays at best a limited role in the protection of traditional knowledge.

\footnotetext{
115 Munzer Theory of Property 290.

116 Munzer and Raustiala 2009 Cardozo Arts \& Ent LJ 59-60.
} 


\section{The incentive theory}

\subsection{Introduction}

The incentive theory builds on society's interest in intellectual property works, holding that legal protection for intellectual works serves as an incentive for the production of more intellectual works that will ultimately benefit society. ${ }^{117}$ The incentive theory advocates promoting the creation of valuable intellectual works by granting property rights in such works since copyright, patent, and trade secret property protection provide the only adequate incentives for the creation of a socially optimal output of intellectual products. ${ }^{118}$

\subsection{Application of the incentive theory to intellectual property}

The focus of the incentive-based theory falls on users of intellectual property - the grant of property rights to creators is merely a mechanism ensuring future production of intellectual creations. The unintended consequence is that the very mechanism ensuring the production of intellectual creations also restricts availability of current creations. ${ }^{119}$ It may be better to find an equally strong incentive that does not restrict access in this way. Government support for intellectual creations and public ownership would be one such alternative. ${ }^{120}$ If intellectual property decreases access to products more than it increases production of new products, the goal may be better attained by a shorter term for patents and copyright, and eliminating the category of trade secrets. Patents and trade secrets could be used for monopoly purposes instead of incentive purposes, as intended. For these reasons the incentive theory may not justify the institution of intellectual property (as is) as well as it may seem. ${ }^{121}$

Intellectual property law is intertwined with talk about incentives. ${ }^{122}$ The intellectual property grant is variously viewed as a reward for making a

117 Mostert 1987 SALJ 500; Hettinger 1989 Phil \& Pub Aff 47: this utilitarian argument based on incentives is the strongest and most widely utilised justification for patents, copyright and trade secrets.

118 Hettinger 1989 Phil \& Pub Aff 47; the Constitution of the United States of America Article I Section 8 Clause 8 (the so-called Intellectual Property Clause) has specifically taken up the incentive theory in the context of patents and copyright, providing that intellectual property rights are granted "to promote the progress of science and the useful arts".

119 Hettinger 1989 Phil \& Pub Aff 48.

120 Hettinger 1989 Phil \& Pub Aff 48-49; Intellectual Property Rights from Publicly Financed Research and Development Act 51 of 2008.

121 Hettinger 1989 Phil \& Pub Aff 49-50.

122 Ghosh 2008 U III L Rev 1130. 
creative work public; a quid pro quo and as such an exclusive right in exchange for making new works available; and even natural rights theories base the rights on the encouragement of creative activities. The incentive theory predicts little about the structure of intellectual property, holding only that protection should be as strong as possible to create maximum incentive (bar a few exceptions introduced by way of afterthought). ${ }^{123}$

The incentive theory is based on the premise that intellectual property protection is necessary to correct market failures which arise from the high fixed costs of creating and the low marginal cost of distributing the creation. ${ }^{124}$ Using the costs incurred during creation to determine intellectual property rights is problematic because it does not determine how intellectual property systems should be structured, or policies implemented. Ghosh suggests a "re-regulation" of intellectual property that would emphasise the role of allocation and utilisation. ${ }^{125}$ This is useful to South African law, especially during a time when the existing statutes are being reviewed and updated, and it should be done with other fundamental rights in the Bill of Rights in mind.

\subsection{Conclusions on the incentive theory and intellectual property rights}

The incentive theory highlights the difficulties in finding a balance between an incentive to create and reasonably open access to information. In the case of patents, copyright and registered designs, an incentive may be necessary to ensure the creation of these intellectual works that may be useful to society. However, there are questions whether the intellectual property system in its current form fulfils the incentive purpose. Trademarks do not seem to be reliant on incentives granted in the form of intellectual property rights, since the incentive behind trademark creation is probably to distinguish products or services in order to promote business.

123 Ghosh 2008 U III L Rev 1131; Ghosh 2006 SCRIPT-ed 97-98. See fn 102 on the exceptions to patentability. Ss 12-19 of the Copyright Act 98 of 1978 provide for exceptions, for example s 12(1) which provides for fair dealing. $S 10(1)-(17)$ of the Trade Marks Act 194 of 1993 state the kinds of trademarks that are not registrable, for example s 10(12): "a mark which is inherently deceptive or the use of which would be likely to deceive or cause confusion, be contrary to law, be contra bonos mores, or be likely to give offence to any class of persons". S 14(6) is an example from the Designs Act 195 of 1993 excluding spare parts from functional design protection, arguably for purposes of protecting free market competition.

124 Ghosh 2008 U III L Rev 1131-1132.

125 Ghosh 2008 U III L Rev 1128. 
With confidential information and trade secrets, there is no benefit to the community because no information is made public. Whether the incentive theory is useful to justify a particular intangible property interest or not hinges on its usefulness to society, and whether information is being made public.

Biotechnological products are valuable to society, and some form of incentive is necessary to ensure their continued production. They would only be included if they are not excluded from protection (by reason of moral non-excludability) in terms of the exclusions in patent law or in light of public interests such as the public domain or a private interest such as the right to freedom of expression, privacy or bodily integrity.

For traditional knowledge the incentive theory has even less application than the reward theory, since incentives in the form of intellectual property were not necessary for the creation of (existing) traditional knowledge. The concern with traditional knowledge is to keep unauthorised persons from exploiting the knowledge. ${ }^{126}$ A suggestion as to how cultural rights of an indigenous group may be protected includes

\begin{abstract}
... a claim right to its TK; a power to create rules that bind others in regard to the copying or reverse-engineering of its TK; a claim-right to receive just compensation for granting access to its TK; a power to seek and a claim-right to have a wide range of remedies for others' failure to pay compensation or obtain informed consent; and lastly powers to modify otherwise applicable laws of patent and copyright. ${ }^{127}$
\end{abstract}

\title{
5 Spiritual theories
}

The personality theory as derived from the writings of Kant ${ }^{128}$ and Hegel, ${ }^{129}$ holds that a property right in a creation must be granted before a creator can be fully in control of their spirit and personality. ${ }^{130}$ Hegel's ${ }^{131}$ writings aim to "reveal the role that community plays in the evolution of individual freedom". ${ }^{132}$ On Drahos'133 interpretation of Hegel's writings on property, intellectual property may have negative effects on community.

\footnotetext{
126 Munzer and Raustiala 2009 Cardozo Arts \& Ent LJ 73.

127 Munzer and Raustiala 2009 Cardozo Arts \& Ent LJ 73.

128 Kant Critique of Practical Reason.

129 Hegel Philosophy of Right para 41-71.

130 See Ciro 2005 JILT 4. See also Maniatis 2002 IPQ 153-166 on the application of the spiritual theories to trademarks.

131 Hegel Philosophy of Right para 10.

132 Drahos Philosophy of Intellectual Property 73.

133 Drahos Philosophy of Intellectual Property 74.
} 
Property rights and personality may be linked in the case of copyright (which provides property rule-type protection to literary, artistic and dramatic works). The link between personality and ownership of the creative work looks strong in these instances. ${ }^{134}$ Justifying intellectual property rights that involve the personality creatively via Hegel's personality theory may be illadvised. Contrasting the property theories of Locke and Hegel by reference to labour and personality may not be the best approach, since Locke's theory ${ }^{135}$ approaches property as serving the personality, while Hegel's theory sees property as the "embodiment of personality". ${ }^{136}$ Also, Hegel's theory views individual property ownership as contradictory. ${ }^{137}$

"Private property can be justified as a means to sovereignty", which means that to achieve individual autonomy, a person must have dominion over certain objects. ${ }^{138}$ When applying this to copyright and patents, one has to distinguish carefully between the creator's right to use his invention or copyright work (which is not granted by the intellectual property system) and the right to prevent others from using the invention or work of copyright in certain ways (as provided by the intellectual property system). While preventing a person from using his own invention or work would threaten his sovereignty, not having the right to exclude others would not necessarily affect this sovereignty.

A personality justification is often viewed as the most powerful alternative to a labour theory for the justification of intellectual property: "[P]roperty provides a unique or especially suitable mechanism for self-actualization, for personal expression, and for dignity and recognition as an individual person". 139

Radin's ${ }^{140}$ "personhood perspective" holds that in order to be a person, one has to have control over certain resources in the external environment, and the control must be fulfilled by property rights. Whether an (intellectual) property interest may be justified by the personality theory depends on how central a particular interest is to the fulfilment of personhood. ${ }^{141}$ This

\footnotetext{
134 Drahos Philosophy of Intellectual Property 74-75.

135 Locke Second Treatise of Government ch V.

136 Hegel Philosophy of Right para 51.

137 Drahos Philosophy of Intellectual Property 75.

138 Hettinger 1989 Phil \& Pub Aff 45.

139 Hughes 1988 Geo LJ 330.

140 Radin 1982 Stan L Rev 957-1015.

141 Radin 1982 Stan L Rev 959-960: Certain items of property are closer to personhood, for example a wedding ring or a house. A wedding ring at a jeweller's shop would be replaceable, while the ring would not be replaceable if it were lost by a person who wears the wedding ring.
} 
approach distinguishes between fungible property and personal property, with a stronger moral claim for the protection of property which serves personhood than for fungible property. ${ }^{142}$

Basically, some forms of property are more worthy of protection than others, and should enjoy more stringent legal protection. The theory uses a continuum, with property closer to the fungible side being more regulatable than property on the personal side (which has a stronger entitlement to protection). ${ }^{143}$ Radin's example of personal property takes the form of a home because it is closely connected to liberty, privacy and freedom of association. ${ }^{144}$ The area of takings law (comparable to expropriation law in South Africa) is an area where this theory can be applied with some success. Courts should be more likely to award compensation for the taking of personal property than for property that constitutes mere monetary loss. ${ }^{145}$

Radin's ${ }^{146}$ personality theory also explores the interaction between fungible property and fundamental rights such as freedom of expression, concluding that fundamental rights should override any interest in fungible property more easily than a personal property interest. It is more difficult to weigh up the interests where both have a personal aspect.

Where a constitutional property case arises, the particular type of property in question must be examined to determine whether an element of personality is present. If not, another constitutional right such as the right to education or freedom of expression would more easily outweigh the property interest, particularly if it also entails a fundamental right. If the property interest does have a personal aspect, the court would have to do more to weigh up the two more equal rights to determine which one must ultimately receive more stringent protection.

It is submitted that intellectual property interests (patents, copyright, designs and trademarks) may be justified by the spiritual theories insofar as they serve to secure a sphere of personal liberty. Copyright and to a lesser extent patent rights are the only categories that appear to be closely linked to the personality, as envisioned by Radin's personality theory. Intangible property rights underpinned by commercial motives (confidential information, trade

\footnotetext{
142 Radin 1982 Stan L Rev 960, 978.

143 Radin 1982 Stan L Rev 986-987.

144 Radin 1982 Stan L Rev 991-1002.

145 Radin 1982 Stan L Rev 1002-1008.

146 Radin 1982 Stan L Rev 1008-1013.
} 
secrets, rights protected by unfair competition principles and probably also trade-mark rights) cannot be justified by the spiritual theories since they are not instrumental in achieving individual autonomy. Traditional knowledge protection could benefit from personality theory justification, since the knowledge is so closely connected to the cultural and spiritual life of the holders of the traditional knowledge. The personality theory could serve as a point of departure in developing a property theory for traditional knowledge, which could form the basis of statutory protection.

\section{Economic theory}

Intellectual property rights are very closely related to markets, since these rights create markets in information. Economic theory is important to justify intellectual property, but has a very wide scope and diverse approaches. For intellectual property, the basic economic theory holds that a market failure arises due to high initial creation costs and marginal distribution costs of intellectual products, so an economic incentive to create must be provided to overcome market failure. ${ }^{147}$

A criticism of this theory is that there is no proof that only property rights can provide this incentive to create. The creators are often not the owners of the property rights, and even if an incentive is provided there is uncertainty as to how much compensation would ensure an adequate incentive. ${ }^{148}$

Where tangible property is concerned, property laws are essentially used to allocate scarce resources among competing needs. The economic argument states that without specific property protection, suppliers would not produce and supply to the market even with the potential for high profits. This argument draws from the free rider principle: opportunists should not be allowed to reap where they have not sown, otherwise there would not be incentive to invest skill and resources to create. ${ }^{149}$ The other side of this argument is that free riders provide competition, without which there would be undesirable monopolies. Arguably, this is the reason why there are limited durations imposed on intellectual property monopolies. ${ }^{150}$

\footnotetext{
147 Drahos Philosophy of Intellectual Property 6; Ciro 2005 JILT 6: "Intellectual property laws produce an artificial restriction that creates the scarcity problem and are then used to allocate scarce resources through a complex web of private property rights controlled by intellectual property owners."

148 Ciro 2005 JILT 4.

149 Ciro 2005 JILT5-7.

150 Ciro 2005 JILT 5. Compare Boyle 2000 Vand L Rev 2007-2039.
} 
Intellectual property is not inherently scarce like tangible property; its scarcity is created through legislation granting property rule-type protection. The market failure justification is therefore not applicable, since market value is based on artificial scarcity created through property legislation and not purely market demand. Instead a market instrumental justification is used by economists to deem the property system as the only workable option. ${ }^{151}$

The basic economic theory as applied to intellectual property may be explained as follows:

Information is a public good, non-excludable and non-rival. It is hard to stop one unit from satisfying an infinite number of users at zero or close to zero marginal cost. Under such conditions, producers of information and information goods will have inadequate incentives, leading to underproduction... The solution to this public goods problem is intellectual property. By creating a limited monopoly called an intellectual property right, we can give producers an adequate incentive to create. ${ }^{152}$

Unfortunately, this argument may also be used to expand the reach of intellectual property unduly. With digitisation, intellectual goods become less rivalrous and less excludable, which arguably requires stronger intellectual property protection. However, intellectual property rights also create monopolies, which usually impose losses from an economic viewpoint. In theory, it might be expected that the benefits reaped through encouraging innovation would be offset by the costs of the monopoly. This "seems to suggest that the idea of a perfect market in information is internally contradictory even in theory". ${ }^{153}$

The basic economic theory does not answer the question of how much the reward should be or what form it should take. A property right is not necessarily the only way to provide compensation or incentive. However, all forms of intellectual property are created through financial investment, which renders this theory applicable. They have high initial costs, but afterwards production and distribution can take place at very low cost. Without some form of protection, some intellectual property products may not be created, since creators and investors may not be willing to expend money and effort.

\footnotetext{
$151 \quad$ Ciro 2005 JILT5.

152 Boyle 2000 Vand L Rev 2012.

153 Boyle 2000 Vand L Rev 2012-2013; Ciro 2005 JILT 6: Intellectual property rights award monopoly rights, which may be anti-competitive. It is market value rather than market failure that may be used to explain the creation and protection of intellectual property.
} 


\section{Theory of natural monopoly}

As mentioned, intellectual property rights create monopolies. The cost structure that governs intellectual property (justifications for the exclusive rights granted by reference to the high fixed costs of production and the small marginal distribution cost of the subject matter of intellectual property) also applies to monopolies and their regulation. Along these lines, Ghosh ${ }^{154}$ developed a theory of natural monopoly as an alternative metaphor for intellectual property. Applying criticisms of natural monopoly to intellectual property challenges the exclusivity of intellectual property, assisting in developing intellectual property law in a more public interest-oriented way. This entails transforming regulation structures rather than extinguishing them.

Ghosh $^{155}$ identifies three types of criticisms of natural monopoly that may successfully be applied to re-regulate intellectual property: questioning assumptions about information and cost; exploring the idea that decreased government regulation would be possible if there were potential competition; and supposing that the politics and economics of regulation should take into account the political reform and recognition of consumer interests.

In the area of inventing, high fixed costs and low distribution costs are often cited to justify intellectual property exclusivity. This justification is similar to the one for a natural monopoly: the combination of high fixed costs and low distribution costs would drive the market down to zero, therefore artificial scarcity through exclusivity is necessary in order to avoid competition that would destroy the market. ${ }^{156}$

Ghosh's ${ }^{157}$ application of natural monopoly criticisms to intellectual property suggests that in determining how much incentive is required to ensure continued creation, a re-regulation is necessary. This approach of viewing

154 Ghosh $2008 \cup$ III $L \operatorname{Rev} 1128,1138-1139$ : "A natural monopoly arises when the average costs of producing a product or service declines as more of the product or service is supplied to the market. Because of declining average costs, it is more efficient from the perspective of lowering the average cost of production to have one firm service the market rather than duplicate expenditures. Average costs are falling either because there are huge fixed costs to production or because the costs of producing an additional unit of the product or service are negligible". See Berg and Tschirhart Natural Monopoly Regulation 12-24; Spulber Regulation and Markets 513-514.

155 Ghosh 2008 U III L Rev 1154. Also see Ghosh 2006 SCRIPT-ed 101.

156 Ghosh 2008 U III L Rev 1157-1158, 1159: "Natural monopoly-like justifications for intellectual property are most prevalent in the controversial areas of database protection, computer software, and biotechnology".

157 Ghosh 2008 U III L Rev1160-1166. 
intellectual property as part of public law (in other words constitutional principles are applicable) acknowledges that the purpose of property is not only to strengthen private rights, but also to loosen exclusionary rights. It implies that the traditional view of strong property rights must shift towards a regime that recognises limits on exclusion. This theory was developed with the intellectual property categories of patents, copyright, designs, trademarks and trade secrets ${ }^{158}$ in mind, and suggests how intellectual property products may be regulated in order to leave space for other rights and interests such as the public domain, the right to education and the right to freedom of expression.

\section{Conclusion}

This article asks why and under which circumstances intellectual property rights and other intangible property interests should and could be recognised and protected under the constitutional property clause.

The natural-law theory principle that a person should have property in that which he has created by his own intellectual effort and exertion has played a large role in the recognition of intellectual property rights, but should not be the sole justification. While the labour theory is still a strong theory for the justification of the protection of intellectual property rights (particularly patents, copyright, registered designs and trademarks), it becomes clear that it does not justify unlimited rights, but rights subject to private and public interests. Intellectual property rights are physically non-excludable, but legally excludable where statutes afford protection and such protection is invoked by the holder of a particular resource. There are also certain morally non-excludable resources that need to stay in the public domain - and intellectual property statutes provide some exceptions for these. Biotechnological products, particularly DNA-related inventions, may sometimes provide an example of a resource that may by morally nonexcludable and as such would not receive any property rule-type protection in either private law or constitutional law.

Traditional knowledge is generally not justified by the labour theory, but rather theories of distributive justice or human rights. Applying the labour theory leads to the reward of only the last person who laboured on the work, usually eliminating the traditional community from any reward.

158 In American law, trade secrets are regarded as a category of intellectual property. 
According to the reward theory, an individual should be rewarded for own labour and effort, but also for creative efforts that benefit society. Currently the creative individual is rewarded by way of an exclusive intellectual property right for a limited period of time, but the reward theory does not indicate that this would be the only appropriate form that the reward could possibly take. This is applicable where intellectual property facilitates the disclosure of works that would otherwise have remained secret, and where it enhances the free flow of information.

The incentive theory holds that if creative works are protected by law and creators are awarded some form of benefit, then this would motivate other creative individuals to create new intellectual works, and this will benefit society. A balance must be found between providing an incentive to create and the public's access to these creations and inventions.

The reward and incentive theories are based on the idea that the disclosure of useful information should be rewarded by a property right. Where information is not disclosed (see for example trade secrets and confidential information) these theories are not useful. Patents, copyright and registered designs may be justified by the incentive and reward theories, but trademarks do not appear to confer any particular benefit on society except for prohibiting the confusion of the products or services sold under the trademark with other similar products or services, which is possibly not the kind of benefit envisioned by the reward theory. Traditional knowledge finds no benefit from either the reward or incentive theory.

The spiritual theories state that an author's personality, spirit and will cannot be free unless the author is also the owner of the work created. A person must have dominion over certain objects in order to achieve individual autonomy. In the context of intellectual property rights, a creator's right to use his invention must be distinguished from the right to prevent others from using the invention. This theory has been developed into the personality theory, which states that a person has to have control over certain resources in the external environment in order to be a person and such control needs to be fulfilled by property rights. The question whether an intellectual property interest may be justified by the personality theory or not depends on how central an interest is to the fulfilment of one's personhood. The spiritual theories may serve to justify the protection of intellectual property only to the extent that they serve to secure a sphere of personal liberty, and as far as they do not fall into the category of moral non-excludability. The 
personality theory as envisioned by Radin ${ }^{159}$ is perhaps only applicable in the context of intellectual creations that are closely related to the personality, therefore perhaps only copyright. Traditional knowledge protection could possibly benefit from the personality theory since the knowledge is sometimes so closely connected to the cultural and spiritual life of the holders of the traditional knowledge. It might serve as a point of departure in developing a theory specifically for the justification of the protection of traditional knowledge. The other intangible property categories arguably constitute fungible property.

The economic theory is most commonly used to justify the protection of intellectual property rights (patents, copyright, designs and trademarks), since they have high initial costs and low distribution costs and some form of protection (through legislation imposing artificial scarcity) is necessary in order to ensure continued investment in the creation of intellectual products. According to the theory it is necessary to grant a limited monopoly in the form of an intellectual property right. However, these monopoly rights may also be seen as anti-competitive.

This necessitates consideration of the theory of natural monopoly as a criticism of the intellectual property system. The justification by reference to the high fixed costs of production and the small marginal distribution cost of the subject matter of patents, copyright and trademarks also justifies the protection of natural monopolies and their regulation. Hence the theory of natural monopoly can also inform the regulation of intellectual property. Understanding intellectual property as a system of regulation brings it under public law. This assists in altering the exclusivity of intellectual property rights to include other rights and interests, for example the public domain.

The public domain or intellectual property commons consists of creative works that are not protected by intellectual property rights. Some interests are incapable of being owned by virtue of their legal nature and others are kept in the public domain as a matter of policy. Some may be described as morally non-excludable. Certain aspects of intellectual property protected works fall in the public domain. These are provided for in the legislation governing each category of intellectual property (for example the fair use exception in the South African Copyright Act 98 of 1987). The public domain entails free use, although this means unrestricted use rather than use without payment. In other words, everyone would have access upon the payment of some flat fee and the holder of an intellectual property right

159 Radin 1982 Stan L Rev 957-1015. 
would not be able to exclude certain persons from the use of a work. The public domain is an important interest which should be developed as a right rather than a privilege, since it is important to keep raw creative materials out of the property regime so that it can be used freely in future creative works.

These theories may be used as a starting point in determining the relative value of an intellectual property right where it conflicts with a fundamental right such as the right to health, education or freedom of expression. Once the relative value has been determined, then the enquiry can proceed to balance the two constitutional rights in question or give effect to the property right in the space left by the non-property fundamental or constitutional right, as may be required in the particular case.

\section{Bibliography}

\section{Literature}

Badenhorst, Pienaar and Mostert Silberberg and Schoeman's The Law of Property

Badenhorst PJ, Pienaar JM and Mostert H Silberberg and Schoeman's The Law of Property $5^{\text {th }}$ ed (LexisNexis Butterworths Durban 2006)

Berg and Tschirhart Natural Monopoly Regulation

Berg SV and Tschirhart J Natural Monopoly Regulation: Principles and Practice (Cambridge University Press New York 1988)

Blignaut "Copyright"

Blignaut $\mathrm{H}$ "Copyright" in Dean $\mathrm{OH}$ and Dyer $\mathrm{A}$ (eds) Introduction to Intellectual Property Law (Oxford University Press Cape Town 2014) 1-76

Boyle 2000 Vand $L$ Rev

Boyle J "Cruel, Mean, or Lavish? Economic Analysis, Price Discrimination and Digital Intellectual Property" 2000 Vand L Rev 2007-2039

Burrell South African Patent and Design Law

Burrell TD Burrells South African Patent and Design Law $4^{\text {th }}$ ed (LexisNexis Durban 2016)

Calabresi and Melamed 1972 Harv L Rev

Calabresi G and Melamed AD "Property Rules, Liability Rules, and Inalienability: One View of the Cathedral" 1972 Harv L Rev 1089-1128 
Ciro 2005 JILT

Ciro T "The Scarcity of Intellectual Property" 2005 JILT 1-21

Dean Handbook of South African Copyright Law

Dean OH Handbook of South African Copyright Law (Juta Cape Town 1987 (updated online 2015))

Drahos Philosophy of Intellectual Property

Drahos P A Philosophy of Intellectual Property (Ashgate Aldershot 1996)

Du Bois 2012 SA Merc LJ

Du Bois M "Intellectual Property as a Constitutional Property Right: The South African Approach" 2012 SA Merc LJ 177-193

Epstein $1979 \mathrm{Ga} L J$

Epstein R "Possession as the Root of Title" 1979 Ga LJ 1221-1243

Ghosh 2006 SCRIPT-ed

Ghosh S "The Intellectual Property Incentive: Not so Natural as to Warrant Strong Exclusivity" 2006 SCRIPT-ed 97-108

Ghosh 2008 U III L Rev

Ghosh S "Decoding and Recoding Natural Monopoly, Deregulation, and Intellectual Property" 2008 U III L Rev 1125-1183

Grant "Patents"

Grant T "Patents" in Dean $\mathrm{OH}$ and Dyer A (eds) Introduction to Intellectual Property Law (Oxford University Press Cape Town 2014) 237-282

Gray 1991 Cambridge LJ

Gray K "Property in Thin Air" 1991 Cambridge LJ 252-307

Harms 2009 THRHR

Harms LTC "A Few Negative Trends in the Field of Intellectual Property Rights" 2009 THRHR 175-191

Hegel Philosophy of Right

Hegel GWF Philosophy of Right (Oxford University Press London 1821, trans Knox TM 1952)

Hettinger 1989 Phil \& Pub Aff

Hettinger EC "Justifying Intellectual Property" 1989 Phil \& Pub Aff 31-52 
Hughes 1988 Geo LJ

Hughes J "The Philosophy of Intellectual Property" 1988 Geo LJ 287-366

Kant Critique of Practical Reason

Kant I Critique of Practical Reason and Other Works on the Theory of Ethics

(Longmans, Green and Co London 1788 trans Abbott TK 1898)

Locke Second Treatise of Government

Locke J Second Treatise of Government (Basil Blackwell Oxford 1690 Gough GW (ed) 1976)

Macpherson Political Theory of Possessive Individualism

Macpherson CB The Political Theory of Possessive Individualism (Oxford University Press London 1962)

Maniatis 2002 IPQ

Maniatis SM "Trade Mark Rights - A Justification Based on Property" 2002 IPQ 123-171

\section{Mostert 1987 SALJ}

Mostert $F$ "The Development of the Natural-law Principle as One of the Principles Underlying the Recognition of Intellectual Property. A Historical Survey from Roman Law to Modern-day Law" 1987 SALJ 480-501

Munzer Theory of Property

Munzer SR A Theory of Property (Cambridge University Press New York 1990)

Munzer and Raustiala 2009 Cardozo Arts \& Ent LJ

Munzer SR and Raustiala K "The Uneasy Case for Intellectual Property Rights in Traditional Knowledge" 2009 Cardozo Arts \& Ent LJ 37-97

Nozick Anarchy, State, and Utopia

Nozick R Anarchy, State, and Utopia (Basil Blackwell Oxford 1974)

Petersen $2008 L T$

Petersen J "Lockean Property and Literary Works" 2008 LT 257-280

Pistorius "Introduction"

Pistorius "Introduction" in Klopper HB et al (eds) Law of Intellectual Property in South Africa (LexisNexis Durban 2011) 143-154 
Pistorius "Requirements for the Subsistence of Copyright"

Pistorius $T$ "Requirements for the Subsistence of Copyright" in Klopper HB et al (eds) Law of Intellectual Property in South Africa (LexisNexis Durban 2011) $161-170$

Proudhon What is Property?

Proudhon PJ What is Property? An Inquiry into the Principles of Right and of Government (Dover New York 1840 trans Tucker BR 1970)

Radin 1982 Stan L Rev

Radin MJ "Property and Personhood" 1982 Stan L Rev 957-1015

Ramsden Guide to Intellectual Property Law

Ramsden P A Guide to Intellectual Property Law (Juta Cape Town 2011)

Rawls Theory of Justice

Rawls J A Theory of Justice (Oxford University Press Oxford 1971)

Rose Authors and Owners

Rose M Authors and Owners. The Invention of Copyright (Harvard University Press Cambridge 1993)

Spulber Regulation and Markets

Spulber DF Regulation and Markets (Massachusetts Institute of Technology Press Cambridge 1989)

Tully Discourse on Property

Tully J A Discourse on Property: John Locke and His Adversaries (Cambridge University Press Cambridge 1980)

Van der Merwe "Introduction"

Van der Merwe A "Introduction" in Klopper HB et al (eds) Law of Intellectual Property in South Africa (LexisNexis Durban 2011) 267-269

Van der Walt $2014 J$ L Prop \& Soc'y

Van der Walt AJ "The Modest Systemic Status of Property Rights" $2014 \mathrm{~J} \mathrm{~L}$ Prop \& Soc'y 15-106

Van der Walt and Du Bois 2013 Stell LR

Van der Walt AJ and Du Bois M "The Importance of the Commons in the Context of Intellectual Property" 2013 Stell LR 31-54 
Van der Walt and Shay 2014 PELJ

Van der Walt AJ and Shay RM "Constitutional Analysis of Intellectual Property" 2014 PELJ 52-85

Webster and Page South African Law of Trade Marks

Webster GE and Page NS South African Law of Trade Marks $3^{\text {rd }}$ ed (LexisNexis Butterworths Durban 1997 (updated online 2017))

Wilson 1994 UCL Juris Rev

Wilson C "The Proprietary Justifications for the Patenting of DNA" 1994 UCL Juris Rev 229-242

\section{Case law}

\section{Australia}

Victoria Park Racing v Taylor (1937) 58 CLR 479

\section{England}

Millar v Taylor (1976) 4 Burr 2303, 98 ER 201

\section{South Africa}

Biotech Laboratories (Pty) Ltd v Beecham Group Plc 20023 All SA 652 (SCA)

Kalamazoo Division (Pty) Ltd v Gay 19782 SA 184 (C)

Laugh it Off Promotions CC $v$ South African Breweries International (Finance) BV t/a Sabmark International (Freedom of Expression Institute as Amicus Curiae) 20061 SA 144 (CC)

Payen Components SA Ltd v Bovic Gaskets CC 19942 SA 464 (W)

Rapid Phase Entertainment CC v South African Broadcasting Corporation $597 \mathrm{JOC}(\mathrm{W})$

\section{Legislation}

\section{South Africa}

Constitution of the Republic of South Africa, 1996

Copyright Act 98 of 1978 
Designs Act 195 of 1993

Draft Intellectual Property Policy of the Republic of South Africa (Phase 1), 2017

Intellectual Property Laws Amendment Act 28 of 2013

Intellectual Property Rights from Publicly Financed Research and Development Act 51 of 2008

Patents Act 57 of 1978

Trade Marks Act 194 of 1993

United States of America

Constitution of the United States of America, 1787

\section{List of Abbreviations}

Cambridge LJ

Cardozo Arts \& Ent LJ

Ga LJ

Geo LJ

Harv L Rev

IPQ

JILT

J L Prop \& Soc'y

LT

PELJ

Phil \& Pub Aff

SALJ

SA Merc LJ

Stan L Rev

Stell LR

THRHR

U III L Rev

UCL Juris Rev

Vand L Rev
Cambridge Law Journal

Cardozo Arts and Entertainment Law Journal

Georgia Law Journal

Georgetown Law Journal

Harvard Law Review

Intellectual Property Quarterly

Journal of Information, Law and Technology

Journal of Law, Property and Society

Legal Theory

Potchefstroom Electronic Law Journal

Philosophy and Public Affairs

South African Law Journal

South African Mercantile Law Journal

Stanford Law Review

Stellenbosch Law Review

Tydskrif vir Hedendaagse Romeins-

Hollandse Reg

University of Illinois Law Review

UCL Jurisprudence Review

Vanderbilt Law Review 